\title{
THE IMPACT OF RESEARCH RESULTS ON THE RESEARCH EXPENDITURE AT THE U.S. UNIVERSITIES
}

\author{
by Nguyen Van Phuong ${ }^{1}$
}

\begin{abstract}
The research spending at universities has become an integral part of development strategies among universities in the world. It is also used as one of key indicators to evaluate university ranking. Therefore, many studies have emphasized on the quality of research results and the impact of technology spillovers from universities to industry. However, the previous empirical evidence is ambiguous as well as it has not identified either the necessary time for an inventor to recoup the initial investment or the linkage between startup and research spending. To fulfill unsolved problems from previous studies, the paper focuses on finding the determinants impacting on the research expenditure at universities by employing a panel of the U.S universities from 1998 to 2004. Specifically, we implement the regression model with differentiating both the level effects and the rate effects of patent applications and licensing income, the estimated results imply that an increase in either the number of patent applications or licensing income reduces the short-term research expenditure but increases the long-term rate of research spending growth of average universities. Moreover, we also find that the more startup firms the inventors pursue, the more research spending they receive.
\end{abstract}

Keywords: research expenditure, patent, applications, and university.

\section{INTRODUCTION}

Many governments have been spending a significant capital on the research and development (R\&D) activities at universities ${ }^{2}$. Economists, policymakers and other scholars emphasize on the contribution of science and technology to economic growth and recognize the foundation of scientific and engineering research in creating jobs, generating innovative technologies, spawning new industries, improving health, and producing other economic and societal benefits. However, the efficient public funding for research and development in the institutions has been raising the debates among the governments. In other words, the argument has emphasized on the quality of research results; the impact of technology spillovers from universities to industry. Azoulay et al (2009) find that patenting has a positive effect on the rate of publications and a weak positive effect on the quality of these publications. They conclude that patenting in academic has an ambiguous impact on public research output.

Many studies have focused on analyzing the commercialization process. They consider the difference in property rights between academics and industry. For example, Stephan and Levin (1996) find that there exists the lag between basic research discovery and commercialization. Additionally, the other studies go further

${ }^{1}$ Lecturer at International University-Vietnam National University.Email:songphuong@hotmail.com

${ }^{2}$ Throughout the paper we will use "university" as shorthand for all not-for-profit research institutions. 
to investigate the linkage between faculty and commercialization perspective. Exploring dataset of 102 U.S universities, Lach and Schankerman (2004) find that higher royalty rates increase faculty effort devoted to commercialization. It implies that the more benefit the researchers receive, the higher effort they devote to commercialization process. However, these studies have not showed how long it takes for a patent to be licensed and recoup its initial investment.

Much research effort has been devoted to examining the impact of established firms. Audretsch and Stephan (1999) and Toole and Czarnitzki (2007) find that technology spillovers occur from academics to industry. Many company founders had prior careers in academe. However, these studies have not explored the relationship between the research fund and established enterprises.

This paper employs an unbalanced panel data of the U.S universities and institutes. Along with these above interesting findings has come a renewed emphasis on a question which determinants impact on research expenditures at universities. In other words, we examine the effects of patent applications, licensing income, established firm on the research spending. It is worth noting that to overcome the above unsolved issues from previous studies such as the mixed empirical evidence, the offsetting time, and the linkage between startup and the research spending, we distinguish the short-term from the long-term effects of research results on the research spending.

The rest of the paper is organized as follows. Section 2 provides a review of the related literature on research results at the U.S universities. Section 3 provides a description of the dataset and discuses estimation strategies. Section 4 presents the empirical results. The concluding section discusses some of the implication of our findings.

\section{PRIOR LITERATURE}

The effects of university-based patenting trends are currently debated. On the one hand, the argument has focused on the quality of university patents; the impact of technology transfer from universities and efficient research expenditures at universities (BagchiSen et al, 2004). Azoulay et al (2009), using a panel dataset of 3,862 academic life scientists, find that patenting has a positive effect on the rate of publications and a weak positive effect on the quality of these publications. They conclude that patenting in academic has an ambiguous impact on public research output.

On the other hand, the commercialization process from research results at universities has been concerned by many authors. Stephan and Levin (1996) study the difference in property rights objectives between academics and industry, spell out the shortened lag between basic research discovery and commercialization. Otherwise, Kremer (1998) argues that patents create a little incentive for the initial research, since potential researchers will take consumer surplus into account as determining whether to do research. Additionally, inventors are not interesting in applying patents because it often takes a long time to receive a grant patent. Meanwhile, patent holders will not reward researchers for the externalities that they create for other researchers. In theory, these externalities have either a positive effect, throughout knowledge spillovers, or a negative impact, throughout patent races and patent infringement suit.

As a result, some authors support to change the reward systems to encourage professors to devote their best efforts in R\&D activities at universities. Powell 
and Owen-Smith (1998) suggest that the change is necessary to speed up the outflow of life scientists and weaken the traditional educational and research missions.

The commercialization perspective is also explored. Brown (2000) finds an increased dependence on industry and philanthropy for operating the university; an increased amount of our resources being directed to applied or so-called practical subjects, both in teaching and in research; a proprietary treatment of research results, with the commercial interest in secrecy overriding the public's interest in free, shared knowledge; and an attempt to run the university more like a business that treats industry and students as clients and ourselves as service providers with something to sell. However, the probability of commercialization success relies on how much effort and time have been devoted the project. The more time the faculty-inventors continue to pursue the research projects, the higher degree of commercialization process is successful. Lach and Schankerman (2004), using data for 102 U.S universities, find that the university licensing income has a strongly positive relationship with faculty royalty rates. They find that higher royalty rates increase faculty effort devoted to commercialization.

The other authors pay more attention to establishing new enterprises. The interesting ideas could encourage facultyinventors to pursue a start-up enterprise as their commercialization vehicle. Audretsch and Stephan (1999) find that fifty percent of the scientific founders in their sample of biotechnology firms had prior careers in academe. Toole and Czarnitzki (2007) find that 337 academic scientists receiving the U.S National Institutes of Health grants have pursued in commercialization through the Small Business Innovation Research and Small Business Technology Transfer Programs between 1983 and 1996. Using data on the number of university spin-offs in the U.S from 1994-2004, Toole and Czarnitzki (2010) find that the academic brain drain has an important effect on the knowledge creation in the not-for-profit research industry.

Obviously, risk and uncertainty are inevitable in research, which means that research often generates negative results. However, such results can redirect research into extremely productive directions (Feller, at Workshop Summary 2011) ${ }^{3}$. The basic problem, as Einstein stated, is that "not everything that counts can be counted, and not everything that can be counted counts". Recently, many professors in the U.S universities have actively discussed to find the optional performance measures that enable the policymakers to evaluate the impacts of Federal investment in research during the workshop at the National Academy Press in 2011. They attempted to achieve the objective of the promise of performance measures that provide useful baselines for assessing several forms accountability.

Patents and copyrights enable inventors to become monopolies over goods and services produced using their ideas. Alfred Spector, Vice President at Google, (Summary Workshop, 2011) stated that "Most faculty agree that patents in computer science basically are almost always a bar that reduces the rate of innovation by creating rigidities and without the benefits of the economic incentives that are supposedly being provided. This may not be true in the biotechnologies, but it is true, I believe, in my field." 
However, not all of patents could commercialize to create significant revenue recouping the initial investments. Patents and copyrights lead to serious problems because of inefficient investment. Patents and copyrights create insufficient incentives for research and development $(R \& D)$, since inventors may be claimed for responsibility of socially wasteful investments on reverse engineering to invent around patents. Before a research performance is conducted, the inventors may not know the costs and expected revenues from licensing research results, and may not even be able to conceive some inventions.

The other studies focus on a novel entity in the pharmaceutical industry, a specially crafted institution that exemplifies the strengths and weaknesses of the post-1980 era of commercialized research. This institution is the 'Contract Research Organization' (CRO), which for most intents and purposes did not exist before 1980. What began as small specialized boutique firms offering narrowly targeted outsourcing services to pharmaceutical clients have come to dominate drug development and clinically trial management. Recently, contract research has been developing rapidly with multi-billion dollar revenue. Particularly in pharmaceutical and biotechnology drug developers, the US $\$ 9.57$ billion world market for contract clinical research services is growing at an annual $13.4 \% .{ }^{4}$

Taken together, the observations suggest a growing number of the most concerns about evaluating the efficient expenditures on research at universities throughout the reward system, publications, patents and commercialization. Based on the literature, we investigate the effects of research results on the expenditures on research activities at the U.S universities.
Specifically, the research results are measured throughout the licensing income, patent applications filed and new startup enterprises. Unlike previous studies, this paper separates level and rate effects of the licensing income, a number of patent applications, a number of new start-up enterprises on the research expenditure/ investment. By doing so, it enables us to estimate how long for the affected universities to recoup the initial investment. In particular, we expect that the level of effects of explanatory variables would be negative because academic inventors need a certain time to complete their research projects; to look for potential investors either to license their intellectual property rights or to set up a new start-up company. By contrast, in the long term, the rate effects would be positive since academic inventors have more incentives for filling patent applications; for generating more revenue from commercialization process; and for developing a venture capital company.

\section{DATA AND ESTIMATION STRATEGIES}

\subsection{Data}

We construct a novel unbalanced university-level panel data from the U.S universities by using two sources including the Chronicle of Higher Education and the Association of University Technology Managers. First, the annual data are collected including all research spending, US patents issued, US patents applications filed, start-up companies formed, licenses and options executed and licensing income over 150 the US universities in period 1998-2004. Second, we identify each university code and year to conduct the unbalanced panel data of 1,017 observations after pooling all available data. The dataset is unbalanced panel 
since the total number of universities the annual survey changes from 131 to 158 varies across each annual survey. during the seven years from 1998 to 2004.

Table 1 shows panel information. The universities involving the seven-year The number of universities participating in balanced panel data is 99 .

Table 1. Panel Information

\begin{tabular}{|c|r|rr|}
\hline Year & $\begin{array}{c}\text { Number of } \\
\text { Universities/ } \\
\text { Observations }\end{array}$ & $\begin{array}{c}\text { Number of Universities/ } \\
\text { observations } \\
\text { in 7 year panel }\end{array}$ \\
\hline 1998 & 131 & 99 \\
1999 & 138 & 99 \\
2000 & 142 & 99 \\
2001 & 142 & 99 \\
2002 & 150 & 99 \\
2003 & 158 & 99 \\
2004 & 156 & 99 \\
\hline Total samples & $\mathbf{1 , 0 1 7}$ & $\mathbf{6 9 3}$ \\
\hline
\end{tabular}

Source: The Chronicle Of Higher Education and The Association of University Technology Managers

Table 2 shows the descriptive statistics of main variables. We can easily recognize the mean of research spending in the US institution is very huge, over US\$195 million. The number of patent applications is almost triple times of the number of patent grants per year. It means that it takes a certain time for qualified applications to receive the patent grant.

Table 2. Descriptive statistics of main variables

\begin{tabular}{llrr} 
Variables & Description & $\begin{array}{c}\text { Mean } \begin{array}{l}\text { Standard } \\
\text { Deviation }\end{array} \\
\text { spending (million USD) }\end{array}$ & $\begin{array}{l}\text { Expenditures on research and development at } \\
\text { University }\end{array}$ \\
1_income (million USD) & $\begin{array}{l}\text { Licensing Income at University } \\
\text { p_filed }\end{array}$ & 5.70 & 16.33 \\
Start_up & Number of Patent Application is filed & 21.30 & 32.87 \\
\hline
\end{tabular}




\subsection{Estimation Strategies}

First of all, we investigate the determinants impacting on the research spending at the U.S universities. We rely on the literature of expenditure and investment function where research expenditure/investment depends on the licensing income, a number of patent applications filed, a number of new start-up enterprises and time. The initial estimation model is presented as follows:

$$
\text { spending }_{i t}=\alpha_{0}+\alpha_{1}+l_{\text {income }_{i t}}+\alpha_{2} p_{\text {filed }_{i t}}+\alpha_{3} \text { start }_{u p_{i t}}+\alpha_{4} \text { time }+u_{i}+\varepsilon_{i t}
$$

Where $\mathrm{i}$ denotes university $\mathrm{i}$ and $\mathrm{t}$ denotes year; spending is $_{\text {it }}$ is the research spending of university $\mathrm{i}$ at time $\mathrm{t}$ (year); 1_income $_{i t}$ is the licensing income of university $i$ at time $t$; $p$ filed $_{\text {it }}$ is a number of patent applications filed by university $i$ at time t; start_up ${ }_{i t}$ is a number of new startup enterprises of university $i$ at time $t$; and time denotes year. $u_{i}$ denotes the unobservable university-specific fixed-effect. The university fixed effects control for unobserved university-level heterogeneity. $\varepsilon_{i t}$ denotes the idiosyncratic error.

The possible outcomes of regression equation (1) may not achieve the expected results because the model has not distinguished the short-term from the

$$
\begin{aligned}
\text { spending }_{i t}= & \beta_{0}+\beta_{1} l_{\text {income }_{i t}}+\beta_{2} l_{\text {income }_{i t}} * \text { time }+\beta_{3} p_{\text {filed }_{i t}}+\beta_{4} p_{\text {filed }_{i t}} * \text { time }+\beta_{5} \text { start }_{\text {up }_{i t}} \\
& +\beta_{6} \text { start }_{\text {up }_{i t}} * \text { time }+\beta_{7} \text { time }+u_{i}+\varepsilon_{i t}
\end{aligned}
$$

The estimation results from Equation (2) enable us to examine both the rate and level effects of predictor variables. The rate effect of each explanatory variable is measured by the interaction term between time and explanatory variable. For instance, to examine the level and rate effect of licensing income on the spending, the estimated coefficients of $\beta_{1}$ and $\beta_{2}$ reflect the level and rate effect of licensing income, respectively.

\section{EMPIRICAL RESULTS}

As pointed out above, faculty takes some time to explore new ideas. Those new ideas were carefully selected and appointed the best candidate to file a patent long-term effects of explanatory variables. It often takes time for inventors to complete their research projects, fill patent applications as well as look for potential partners to licensing patents or copyrights. Regardless of time trend, the level of effects of predictor variables is negatively associated with the recurrent budget for research expenditure at year $t$. Therefore, to precisely evaluate the efficient investment in research activities at universities, we need to examine the rate effects of predictor variables. To test the rate effects, the regression equation (1) is rewritten with more detail information to implement the regression analysis as follows:

application. Similarly, seeking a potential partner to sign an agreement contract for using a granted patent or copyright also takes some time and efforts. Therefore, the performance measures of the effective investment in research activities should be considered in the long-term effect. In other words, we expect to find the rate effects of patent applications and licensing income to have a positive impact on the spending or investment in research.

We implement two regression models as mentioned in Equation (1) and (2) to test the impacts of research results on the research expenditure at the U.S universities. We add to all of the models a full set of 
university fixed effects ${ }^{5}$. Controlling for university fixed effects enables us to avoid the possible reverse causality that some states with large public finances could provide more funds for research and more productive universities receive more government financial assistance grants. Furthermore, it is worth noting that all coefficient estimates involved are corrected for heteroskedasticity.

The estimated results are presented in Table 3. In the first column, we estimate regression equation (1) regardless of time trend. Only two coefficients of patent applications and time are statistically significant at the $1 \%$ level. Meanwhile, the estimated coefficient of licensing income is negative and that of new startup enterprises is positive. Nonetheless, both of them are not statistically significant. It means that the regression equation (1) is not a good fit to test our expectation.

Now we consider the regression equation (2) as the interaction terms of time trend included in the model. Intuitively, when researchers receive the fund for performing the research projects, it only begins the initial stage. The inventors take some time to come up with many ideas, choose the best one and turn that one into an invention. This process varies from invention-to-invention and from inventor-to-inventor. Once the invention is completely developed, and the inventors seriously consider patent protection, they often engage in the services of patent practitioner to file patent application. Generally speaking, this process is a long period and patent pending often takes approximately at least one year. Therefore, to evaluate the impact of research results, we need to consider both short-term and long-term effects.
The level effects of research results may be either negative or positive. On the one hand, the negative results may occur when a research project has been fully finished and inventors either engage in the services of patent practitioner to file patent application or achieve the licensing agreement. Simultaneously it means that the spending on the project could decrease or stop. In other words, there is no more expenditure on the research project when it has already completed. Therefore, we expect the both level effects of patent applications and licensing income will be negative.

On the other hand, the positive result may take place if inventors at a university have already utilized their research results throughout pursuing to set up an established firm or a startup. For instance, people who received industry funding were less interested in a faculty research and teaching career and more interest in working either for a start-up or for an established firm (Workshop Summary, 2011). Thus, the estimated coefficient of startup is expected to be positive.

As the rate effect of research results is separated from the level effect, it is expected to be generally positive. There may be two reasons for this. Firstly, research results require a certain time to complete the project or to seek a potential partner to achieve the agreement for using patents or copyrights. Secondly, as completing an old project, to receive a new funding for a new research project, inventors have to restart the procedures to get approval for the new one. Therefore, as time goes on, the higher growth rate of licensing income and patent applications lead to an increase in more investment funds for research projects. 
In the second column of Table 3, almost all of the estimated coefficients are statistically significant at least at the $5 \%$ level, except for the interaction term between startup and time. First, we consider the estimated results of patent applications filed and its interactive term. As our expectation, the estimated coefficient of patent applications filed is negative and statistically significant at the $1 \%$ level. This result implies that a $10 \%$ increase in the number of patent applications will lead to a reduction in the spending on research by approximately $4.9 \%$. This also implies that the more patent applications are filed in year $t$, the less expenditure on research takes place concurrently. Meanwhile, the coefficient of the interaction term (p_filed* time) is positive and statistically significant at the $1 \%$ level. This result implies that the same level of a $10 \%$ increase will lead to increasing the rate of the spending growth of average universities by around $1.8 \%$. Overall, according to the results, an increase in the rate of spending growth of average universities may allow the affected universities to offset the initial budget deficit in the spending level in about three years (=round $(0.494 / 0.178)$ ). The time is necessary for receiving the research funds since the starting process of selecting an interesting idea until the ending process of achievement.

Second, the estimated coefficient of licensing income is negative and statistically significant at the $5 \%$ level. Meanwhile, the estimated coefficient of the interaction term between licensing income and time is positive and statistically significant at the $5 \%$ level. These estimates are similar to the case of patent applications. Particularly, a 10\% increase in the licensing income will lead to a reduction in the spending level of average universities by approximately $7.78 \%$ while concurrently leading to increasing the rate of spending growth of average universities by around $1.7 \%$. The results imply that the increase in the rate of spending growth due to an increase in licensing income will enable universities to recover the initial budget deficit in the spending level in about 4.6 years. This result is consistent with the previous finding of Stephan and Levin (1996). They identify that there is a lag between basic research and commercialization. In addition, this result is also consistent with the previous finding of Lach and Schankerman (2004). However, they did not differentiate the level from the rate effect of application research result. Obviously, it takes more time to recoup the initial investment in research throughout collecting licensing income.

Some authors found the strong linkage between firms and institutions in patenting activities. They conclude that firms with university partnerships generally have greater productivity and larger patenting activity than those without, and that a major motive for the firm to perform such collaboration is to achieve access to university academic researchers and maximize university's capacities and laboratory facilities (Audretsch et al, 2005). However, our survey and empirical analysis proved that there is still a large gap between patents and their commercial applications. In other words, the efficient research spending in the US institutions has not achieved the initial goals. The licensing income from patents and copyrights is less than $3 \%$ of total expenditures. This leads to many debates about effective public spending for R\&D activities in universities. Moreover, it takes a longer period (more than 4 years) for licensing income to offset the initial research investment.

We also synthesize three main causes of low return on investment in research 
including i) the quality of patents, ii) the This result implies that the more startup high cost of pursuing patent and iii) the or established firms are pursued, the larger lack of promotion policies to spur the research funds the inventors could receive. commercialization process. In our point of This result is consistent with the previous view, the first one is accounting for a very findings from several studies such as small proportion because a patent is too Audretsch and Stephan (1999), Toole and tough to get approved by the US Patent and Czarnitzki (2007) and Toole and Czarnitzki Trademark Office. Therefore, the second (2010). Meanwhile, the estimated and third one seem to be mainly considered. coefficient of (startup*time) is negative but

Last but not least, the estimated not statistically significant. It means that coefficient of startup is positive and there is no evidence of the rate effect of statistically significant at the $5 \%$ level. startup on the research spending growth.

Table 3. Estimating the level and rate effects of research results

\begin{tabular}{|c|c|c|}
\hline & Spending on $\mathrm{R} \& \mathrm{D}$ & Spending on R\&D \\
\hline & Equation (1) & Equation (2) \\
\hline \multirow[t]{2}{*}{ p_filed } & $0.9883 * * *$ & $-0.4940 * * *$ \\
\hline & $(0.1621)$ & $(0.1175)$ \\
\hline \multirow[t]{2}{*}{$p_{\text {_filed*time }}$} & & $0.1787 * * *$ \\
\hline & & $(0.0156)$ \\
\hline \multirow[t]{2}{*}{ 1_income } & -0.3967 & $-0.7785^{* *}$ \\
\hline & $(0.3260)$ & $(0.3851)$ \\
\hline \multirow[t]{2}{*}{ 1_income*time } & & $0.1704 * *$ \\
\hline & & $(0.0780)$ \\
\hline \multirow[t]{2}{*}{ start_up } & 0.4976 & $4.0760 * *$ \\
\hline & $(2.1172)$ & $(1.9676)$ \\
\hline \multirow[t]{2}{*}{ start_up*time } & & -0.3865 \\
\hline & & $(0.4202)$ \\
\hline \multirow[t]{2}{*}{ time } & $11.9569 * * *$ & $4.0688 * * *$ \\
\hline & (1.0973) & $(0.9650)$ \\
\hline$N$ & 1017 & 1017 \\
\hline$R^{2}$ & 0.9734 & 0.9847 \\
\hline
\end{tabular}


The dependent variable is spending on research and development at university. The first column is estimated the level effects. While the second column is estimated both level and rate effects. All regression models include university fixed effects and constant but not reported in table. Standard errors in parentheses under coefficients are robust to heteroskedasticity. * Significant at the $10 \%$ level. ** Significant at the 5\% level. $* * *$ Significant at the $1 \%$ level.

Generally, the resulting estimates reported in the first two cases are consistent with our theoretical expectations that the number of patent applications and licensing income have a negative impact on the short-term level but a positive impact on the long-term rate of research spending growth. Together, they indicate that these two research results benefit average universities in the long run. Furthermore, the increase in the number of established firms will lead to the increasing in the research funds. This is also consistent with our expectation. It implies that there is a strong linkage between academics and industry. As a result, research funders and performers should work with the private sector in measuring the impacts of research, since the private sector devotes considerable time and money working on this issue.

\section{CONCLUSION}

Using a panel of the U.S universities from 1998-2004 to examine the impacts of research results on the research expenditures, we find some interesting results. First, as differentiating both the level effects and the rate effects of patent applications and licensing income, the estimated results confirm our expectation that an increase in either the number of patent applications or licensing income decreases the short-term research spending but increases the long-term rate of research spending growth of average universities. It takes a longer time for licensing income to offset the initial investment than for patent applications. These results may explain at least in part why previous study on patenting in academic has an ambiguous impact on public research output (Azoulay et al (2009)). Therefore, the differentiation of the level from rate effect of research results in empirical studies is very important. In second scope of the paper, we also find the strong linkage between startup or established firms and research spending. The more startup the inventors pursue, the larger research funds they achieve.

Here, our results assist the government to leverage and validate allocation of public funding between commercial applications and $R \& D$ based on activities in the universities. Specifically, the government who deal with the limited budget constraints for research spending such as the Vietnamese government can withdraw from the learning experience when allocating the research funds to universities and performing measures of the efficient return on investment in research.

In order to analyze carefully which factors are the main reasons affecting the efficient public funding in universities, we need to implement the further study. For instance, we could classify patents issued into particular industries or into forms of collaboration researches and then we could delivery better conclusion for specific sectors. 


\section{REFERENCES}

1. Audretsch, D.B., and P.E. Stephan, "Knowledge spillovers in biotechnology: sources and incentives." Journal of Evolutionary Economics, 1999, 97-107.

2. Audretsch, David B., Erik E. Lehmann, Susanne Warning. "University spillovers and new firm location." Research Policy, 2005, 1113-1122.

3. Azoulay, Pierre, Waveerly Ding, and Toby Stuart, "THE IMPACT OF ACADEMIC PATENTING ON THE RATE, QUALITY AND DIRECTION OF (PUBLIC) RESEARCH OUTPUT." The Journal of Industrial Economics, 2009, 637-676.

4. Bagchi-Sen S, Lawton Smith H, and Hall L, "The US biotechnology industry: industry dynamics and policy." Environment and Planning C: Government and Policy, 2004, 199-216.

5. Brown, James Robert, "Privatizing the University-the New Tragedy of the Commons." Science, 2000, 1701-1702.

6. Czarnitzki, D., and Toole A. A, "Is there a trade-off between academic research and faculty entrepreneurship? Evidence from U.S. NIH supported biomedical researchers." Economics of Innovation and New Technology, 2010, 505-520.

7. Czarnitzki, D., and Toole A. A, "Commercializing Science: Is there a University Brain Drain from Academic Entrepreneurship?" Management Science, 2010, 1599-1614.

8. Jaffle, Adam, "Technological Opportunity and Spillovers of R\&D: Evidence from Firm's Patents, Profits, and Market Value." American Economic Review, 1986, 984-1001.

9. Kremer, Michael, "Patent Buyouts: A Mechanism for Encouraging Innovation." The Quarterly Journal of Economics, 1998, 1137-1167.

10. Lach, Saul and Mark Schankerman, "Royality Sharing and Technology Licensing in Universities." Journal of the European Economic Association, 2004, 252-264.

11. Powell, Walter W. and Jason Owen-Smith, "Universities and the market for intellectual property in the life sciences." Journal of Policy Analysis and Management, 1998, 253-277.

12. Stephen, P.E., and S.G. Levin, "The Economics of Science." Journal of Economic Literature, 1996, 1199-1235.

13. Summary Workshop, "The Promise and Limitations of Performance Measures", THE NATIONAL ACADEMIES PRESS, 2011.

14. Toole, A.A. and D. Czarnitzki, "Biomedical academic entrepreneurship through the SBIR programs.” Journal of Economic Behavior \& Organization, 2007, 716-738.

15. Toole, Andrew A, "The impact of public basic research on industrial innovation: Evidence from the pharmaceutical industry." Research Policy, 2012, 1-12.

16. Wright, Brian D, "The Economics of Invention Incentives: Patents, Prizes, and Research Contract." American Economic Review, 1983, 691-707. 